\title{
Glutamate Inhibits GABA Excitatory Activity in Developing Neurons
}

\author{
Anthony N. van den Pol,1,2 Xiao-Bing Gao, ${ }^{1}$ Peter R. Patrylo, ${ }^{1}$ Prabhat K. Ghosh, ${ }^{1}$ and Karl Obrietan ${ }^{2}$ \\ ${ }^{1}$ Department of Neurosurgery, Yale University, New Haven, Connecticut 06520, and 2Department of Biological Sciences, \\ Stanford University, Stanford, California 94305
}

In contrast to the mature brain, in which GABA is the major inhibitory neurotransmitter, in the developing brain GABA can be excitatory, leading to depolarization, increased cytoplasmic calcium, and action potentials. We find in developing hypothalamic neurons that glutamate can inhibit the excitatory actions of GABA, as revealed with fura- 2 digital imaging and whole-cell recording in cultures and brain slices. Several mechanisms for the inhibitory role of glutamate were identified. Glutamate reduced the amplitude of the cytoplasmic calcium rise evoked by GABA, in part by activation of group II metabotropic glutamate receptors (mGluRs). Presynaptically, activation of the group III mGluRs caused a striking inhibition of GABA release in early stages of synapse formation. Similar inhibitory actions of the group III mGluR agonist L-AP4 on depolarizing GABA activity were found in developing hypothalamic, cortical, and spinal cord neurons in vitro, suggesting this may be a widespread mechanism of inhibition in neurons throughout the developing brain. Antagonists of group III mG luRs increased GABA activity, suggesting an ongoing spontaneous glutamate-mediated inhibition of excitatory GABA actions in developing neurons. Northern blots revealed that many mGluRs were expressed early in brain development, including times of synaptogenesis. Together these data suggest that in developing neurons glutamate can inhibit the excitatory actions of GABA at both presynaptic and postsynaptic sites, and this may be one set of mechanisms whereby the actions of two excitatory transmitters, GABA and glutamate, do not lead to runaway excitation in the developing brain. In addition to its independent excitatory role that has been the subject of much attention, our data suggest that glutamate may also play an inhibitory role in modulating the calcium-elevating actions of GABA that may affect neuronal migration, synapse formation, neurite outgrowth, and growth cone guidance during early brain development.

Key words: hypothalamus; metabotropic glutamate receptor; calcium; developing synapse; spinal cord; cortex
$D$ uring development, the primary inhibitory transmitter of the mature brain, GA BA, assumes an excitatory role. B ecause of an elevated $\mathrm{Cl}^{-}$reversal potential found in immature hypothalamic neurons, activation of the $\mathrm{GABA}_{\mathrm{A}}$ receptor leads to an inward current caused by $\mathrm{Cl}^{-}$efflux, membrane depolarization, $\mathrm{Ca}^{2+}$ influx associated with the activation of voltage-activated calcium channels, and an increase in action potentials ( $C$ hen et al., 1996). The excitatory actions of GA BA are found not only in hypothalamic neurons, the focus of the present study, but also in the majority of developing neurons from all other brain regions we and others have studied, including hippocampus, olfactory bulb, spinal cord, striatum, cerebellum, and cortex (C onnor et al., 1987; C herubini et al., 1990, 1991; Y uste and K atz, 1991; B en A ri et al., 1994; R eichling et al., 1994; L oT urco et al., 1995; O brietan and van den Pol, 1995; Serafini et al., 1995; C hen et al., 1996). D uring development, GA BA can influence neurite outgrowth, branching, synapse formation, cell division, and gene expression (Spoerri, 1988; M ichler, 1990; Barbin et al., 1993; L oT urco et al., 1995); many of these effects of GA BA may be caused by its depolarizing and calcium-elevating actions.

Even at the earliest embryonic times examined in detail [embryonic day 15 (E 15)], all hypothalamic neurons expressed func-

\footnotetext{
R eceived J uly 27, 1998; revised Sept. 28, 1998; accepted O ct. 7, 1998

This work was supported by National Institutes of Health G rants NS 34887, NS 31573, and the National Science Foundation. We thank M s. Y. Y ang for excellent technical help.

Correspondence should be addressed to Dr. A nthony N . van den Pol, D epartment of N eurosurgery, Y ale U niversity M edical School, 333 C edar Street, N ew Haven, CT 06520.

Copyright (c) 1998 Society for N euroscience $\quad 0270-6474 / 98 / 1810749-13 \$ 05.00 / 0$
}

tional $\mathrm{GABA}$ A receptors. M ost neurons also expressed glutamate receptors within the next $3 \mathrm{~d}$ ( $\mathrm{C}$ hen et al., 1995; van den $\mathrm{Pol}$ et al., 1995). Studies in the hypothalamus (C hen et al., 1995) and other brain regions (R eynolds and Brien, 1992; Ben-A ri et al., 1994) suggest that GABA ergic activity develops early and that glutamate activity occurs soon after. This raises the question as to the possible interaction between the two primary transmitters of the brain during early development. If both G A BA and glutamate are excitatory, what prevents the neurons in the developing brain from simply getting caught in a positive feedback cycle of runaway excitation that might lead to seizure-like activity and potentially raise intracellular calcium to cytotoxic levels? At a more local cellular level, can glutamate, rather than summating with GA BA to increase excitation and intracellular calcium, act to reduce GA BA actions, and, thereby, play an important modulatory role in inhibiting excitation at developing GA BA ergic synapses?

In this paper we test the hypothesis that inhibitory actions of glutamate in developing hypothalamic neurons reduce the excitatory activity of GA BA. We used the hypothalamus because of the relati vely large proportion of G A B A ergic cells and presynaptic boutons (Decavel and van den Pol, 1990). Whole-cell patch clamp recording was used to assess fast ionic currents and potentials in cultured neurons and hypothalamic slices. Because cytosolic calcium levels may play an important role in early development, including regulation of transmitter release, gene expression, neuronal migration, programmed cell death, and extension and turning of growing neurites, fura-2 digital calcium imaging was used to examine cytoplasmic calcium responses. N orthern blots were used to test the hypothesis that metabotropic 
glutamate receptors that may modulate GABA activity were expressed very early in brain development. We identify several distinct mechanisms that can account for glutamate-mediated inhibition of GABA excitation in early neuronal development.

\section{MATERIALS AND METHODS}

T issue culture. $\mathrm{H}$ ypothalami were removed from embryonic day 18 rats (Sprague Dawley), dispersed in a papain solution, triturated, and plated on polylysine-coated glass or plastic substrates. D etails are found in our previous papers (Obrietan and van den Pol, 1996; van den Pol et al., 1996).

Fura-2 digital imaging. From 3 to $8 \mathrm{~d}$ after plating, cells on coverslips were loaded with fura-2 AM (Molecular Probes, Eugene, OR) and imaged on a Nikon inverted microscope with an Olympus $40 \times$ objective with high $340 \mathrm{~nm}$ light transmittance. A Sutter L ambda 10 filter wheel was controlled by Fluor software from U niversal Imaging. A rapid perfusion chamber was used, allowing complete washout of agonists within a few seconds. Calcium standards (M olecular Probes) were used to calibrate the system according to the equation of Grynkiewicz et al. (1985). A dditional details have been described previously (van den Pol et al., 1996, 1997).

Whole-cell recording in cultured neurons. Neurons were recorded with patch pipettes (4-6 M $\Omega$ size tip). A n EPC 7 amplifier was used with A xodata and I gorPro software. T wo types of whole-cell recording were used. In conventional recordings, after obtaining a gigaohm seal on the membrane, negative pressure was applied, and whole-cell recordings were obtained. For conventional whole-cell recording, the pipette solution contained (in $\mathrm{mM}$ ): $\mathrm{K} \mathrm{M} \mathrm{eSO}_{4} 116, \mathrm{KCI} 27, \mathrm{M} \mathrm{gCl}_{2} 1, \mathrm{H}$ EPE S 10 , and E GTA 1.1, M g-A TP 4, GTP 0.5, pH 7.3, with $\mathrm{KOH}$. To avoid disturbing the normal intracellular $\mathrm{Cl}^{-}$concentration (R eichling et al., 1994; E bihara et al., 1995) and to demonstrate the depolarizing actions of GA BA, we also used gramicidin perforations for whole-cell recordings, as described in detail in previous papers ( $C$ hen et al., 1996; van den Pol et al., 1996; $\mathrm{G}$ ao et al., 1998). The pipette solution for gramicidin-perforated recording contained (in $\mathrm{mm}$ ): $\mathrm{KCI} 145, \mathrm{M} \mathrm{gCl}_{2} 1$, $\mathrm{HEPES} \mathrm{10,} \mathrm{EGTA} \mathrm{1.1,}$ and 50-100 $\mu \mathrm{g}$ gramicidin, $\mathrm{pH} 7.3$, with $\mathrm{KOH}$. The recording chamber was continuously perfused at a rate of $1.5-2 \mathrm{ml} / \mathrm{min}$ with a bath solution containing (in mM ): $\mathrm{NaCl} 155, \mathrm{KCI} 2.5, \mathrm{CaCl}_{2} 2, \mathrm{HEPES} 10$, and glucose 10, $\mathrm{pH} 7.3$, with $\mathrm{NaOH}$.

$\mathrm{B}$ rain slice whole-cell recording. $\mathrm{H}$ ypothalamic slices from postnatal day 0 (P0)-P5 rats were prepared by conventional techniques. Briefly, rats were anesthetized with sodium pentobarbital (50 mg/ $\mathrm{kg}$, i.p.) and then decapitated. Their brains were rapidly removed and immersed in cold $\left(1-3^{\circ} \mathrm{C}\right)$, oxygenated choline chloride solution (containing in $\mathrm{mm}$ : choline chloride 135, $\mathrm{KCI} 1, \mathrm{NaHCO} 320, \mathrm{NaH}_{2} \mathrm{PO}_{4} 1.2$, dextrose 10, and $\mathrm{M} \mathrm{gSO}_{4}$ 20) for $1 \mathrm{~min}$. Coronal slices $(400 \mu \mathrm{M})$ were cut with a vibratome, trimmed to contain just the hypothalamus, and then placed in a fluid-gas interface-type chamber humidified with $95 \% \quad \mathrm{O}_{2}$ and $5 \% \quad \mathrm{CO}_{2}$ and maintained with a constant flow of artificial C SF (ACSF) at $31-32^{\circ} \mathrm{C}$. The ACSF contained (in mM): $\mathrm{NaCl} 124, \mathrm{KCl} 3, \mathrm{CaCl}_{2} 2, \mathrm{NaHCO}_{3} 26$, $\mathrm{M} \mathrm{gSO}_{4} 1.3, \mathrm{NaH}_{2} \mathrm{PO}_{4} 1.25$, and glucose 11 equilibrated with $95 \% \mathrm{O}_{2}$ and $5 \% \mathrm{CO}_{2}, \mathrm{pH} 7.2-7.4$. Slices were allowed to recover for $\sim 2 \mathrm{hr}$ before recording.

Whole-cell recordings in slices were obtained using patch pipettes (4-7 $M \Omega$ ) pulled on a F laming-Brown puller (Sutter Instruments) and filled with (in mM) $\mathrm{KCI} 145, \mathrm{M} \mathrm{gCl}_{2}$ 1, H EPES 10, EGTA 1.1, M g-A TP 4, and $\mathrm{Na}_{2}$-GTP 0.5. A n A xoclamp-2A amplifier was used with A xodata and IgorPro software. In all experiments cells were kept at hyperpolarized membrane potentials of at least $-75 \mathrm{mV}(-75$ to $-95 \mathrm{mV})$ by applying a steady hyperpolarizing current. C ells were included in this study only if they had input resistances $\geq 100 \mathrm{M} \Omega$ and had action potentials overshooting $0 \mathrm{mV}$. In experiments in which ionotropic glutamate receptors were blocked, C N QX $(25 \mu \mathrm{M})$ and A P5 $(50 \mu \mathrm{M})$ were applied to the bath. To apply bicuculline, L-A P4, and control vehicles, a Picospritzer was used with single- or double-barreled micropipettes. In experiments examining spontaneous depolarizing PSPs, a single drop of bicuculline $(30 \mu \mathrm{M})$ or L-A P4 $(100 \mu \mathrm{M})$ was applied to the surface of the slice. When examining evoked responses, a bipolar stimulating electrode made of teflon-coated platinum-iridium wire $(75 \mu \mathrm{m})$ was used to deliver electrical stimulations $(50-500 \mu \mathrm{A} ; 0.1-0.3 \mathrm{msec} ; 0.1 \mathrm{~Hz})$. C ells were used for these experiments only if electrical stimulation could consistently evoke a PSP before the application of L-A P4.

L-CCG-I ((2S-1'S-2'S)-2-(carboxycyclopropyl)glycine from Tocris Cookson, St. L ouis, M O) and L-A P4 (L-2-amino-4-phosphonobutyrate from Research Biochemicals, Natick, M A) were used to activate the group I /II and III metabotropic glutamate receptors, respectively (Schoepp, 1994; Pin and D uvoisin, 1995; R oberts, 1995). Bicuculline, A P5, and CNQX were obtained from R esearch Biochemicals.

N orthern blots. R N A from hypothalamus, hippocampus, olfactory bulb, cortex, cerebellum, and whole brain was purified as described elsewhere, and $10 \mu \mathrm{g}$ was loaded onto the gel (Ghosh et al., 1997). Northern hybridization was done individually with both D N A restriction fragments isolated from CDNA clones (kindly provided by Dr. S. Nakanishi) and PCR -amplified small DNA fragments synthesized by using each metabotropic glutamate receptor-specific primer on PCR -amplified CDNA templates isolated from rat whole-brain total RNA. The results were identical using both sets of probes. The N orthern results presented here are the results using PCR-amplified small DNA fragments, because these probes gave cleaner results with very little background versus restriction enzyme digested larger DNA fragments. Details are found in our previous papers (van den Pol et al., 1994; G hosh et al., 1997).

\section{RESULTS}

Both calcium digital imaging with fura-2 and whole-cell patch clamp recording with conventional or gramicidin perforations were used to examine parallel aspects of glutamate inhibition in developing neurons in neonatal slices from the developing hypothalamus and from cultured hypothalamic neurons.

\section{High levels of spontaneous GABA activity in developing hypothalamic slices}

In electrophysiological experiments using hypothalamic slices, $\mathrm{KCI}$ patch electrodes were used to determine whether spontaneous GABA-mediated events were present in the neonatal ( $\mathrm{PO}$ P5) mediobasal hypothalamus, focusing on arcuate-ventromedial nucleus neurons. The mean resting membrane potential of these developing neurons $(n=9)$ was $-54 \pm 4.8(S D) \mathrm{mV}$; to increase the ionic driving force, cells were sometimes held between -70 and $-90 \mathrm{mV}$, which facilitated detection of PSPs. Input resistance in these cells was $586 \pm 250$ (SD) $M \Omega$. In 11 of 11 neurons recorded in normal ACSF, large depolarizing events were observed. These PSPs ranged in frequency from $\sim 1$ to $5 \mathrm{~Hz}$ and were reversibly blocked by application of the $\mathrm{GABA}_{\mathrm{A}}$ receptor antagonist bicuculline ( $30 \mu \mathrm{M} ; \mathrm{n}=5$ of 5 neurons examined; Fig. 1 ), suggesting that they were GA BA ergic in nature. To determine whether these events were dependent on ionotropic glutamate receptor activation, additional experiments were performed in the presence of the kainate-A M PA and N M DA receptor antagonists CNQX $(25 \mu \mathrm{M})$ and AP5 $(50 \mu \mathrm{M})$, respectively. In this condition, large depolarizing PSPs (frequency 0.4-4 Hz) were still observed in 12 of 13 neurons examined and were blocked by bicuculline (30 $\mu \mathrm{m} ; \mathrm{n}=3$; Fig. 1). Unlike the adult arcuate nucleus region, in which glutamate provides an important driving force for GA BA activity (Belousov and van den Pol, 1997), in the developing hypothalamus, GABA-mediated potentials are not dependent on classical fast glutamatergic neurotransmission but instead occur spontaneously and frequently.

\section{GABA-evoked calcium rises are depressed by glutamate}

Calcium imaging

GABA and glutamate (each $5 \mu \mathrm{m}$ ) evoke a $\mathrm{Ca}^{2+}$ rise in developing neurons in studies with fura-2 digital imaging. In approximately one-third of the cells tested at 3-4 days in vitro (DIV), GA BA evoked a greater $\mathrm{Ca}^{2+}$ rise than glutamate did (33\% of 119 neurons). In most of these neurons ( $85 \%$ of 39 neurons), the addition of glutamate to the GABA-containing solution depressed the $\mathrm{Ca}^{2+}$ rise evoked by GABA (Fig. 2), suggesting that glutamate inhibited the effectiveness of GABA in generating $\mathrm{Ca}^{2+}$ rises. 


\section{Spontaneous GABA-mediated PSPs in neonatal hypothalamic slices}

A ACSF

1. Control

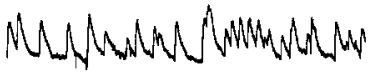

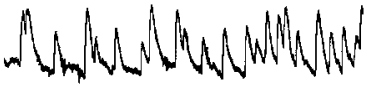

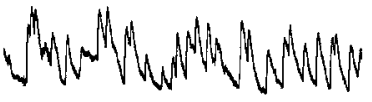

2. Bicuculline
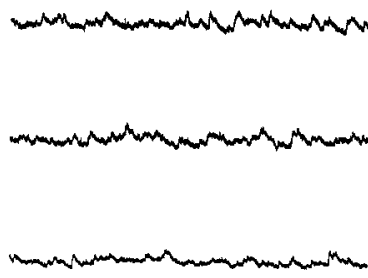

B. ACSF with AP5 and CNQX

1. Control

2. Bicuculline

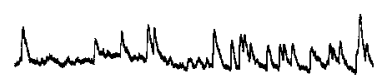

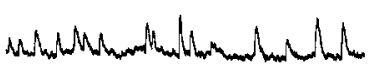

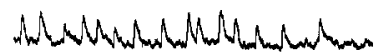

3. Recovery

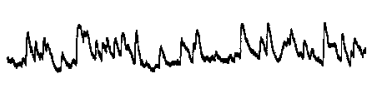

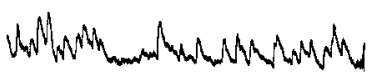

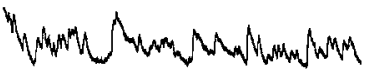

$\frac{20}{1 \mathrm{~s}} \mathrm{mV}$

3. Recovery
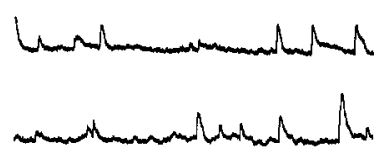

Whal Mudulum
Figure 1. Spontaneous GA BA-mediated postsynaptic potentials in neonatal hypothalamic slices. A, Spontaneous depolarizing PSPs detected with whole-cell recording in a $\mathrm{P} 1$ arcuate-ventromedial nucleus ( $A R C-V M H)$ neuron in normal AC SF were reversibly blocked by the addition of the $\mathrm{GA} \mathrm{BA}_{\mathrm{A}}$ receptor antagonist bicuculline $(30 \mu \mathrm{M})$. A fter bicuculline washout, PSPs recover. B, L arge depolarizing PSPs were also observed in neonatal A R C $-V M H$ neurons in the presence of AP5 $(50 \mu \mathrm{M})$ and CNQX $(25 \mu \mathrm{M})$ and were reversibly blocked by the addition of bicuculline $(30 \mu \mathrm{M})$. This observation suggests that in the developing hypothalamus GA BA -mediated activity is not dependent on ionotropic glutamate receptor activation. The traces in $B$ were obtained in a hypothalamic slice from a P2 rat. $R$ ecordings in $A$ and $B$ were performed using $\mathrm{KCl}$ electrodes, and the membrane potential of these neurons was held at $\sim 90 \mathrm{mV}$ throughout the respective experiments.
Immunostaining for metabotropic glutamate receptors has shown widespread expression in different regions of the adult and developing hypothalamus (van den Pol, 1994; van den Pol et al., 1994, 1995). To test the hypothesis that the glutamate-mediated reduction in $\mathrm{GABA}$-evoked $\mathrm{Ca}^{2+}$ rise was in part caused by activation of metabotropic glutamate receptors (mGluRs), we used two group I/II nonselective mGluR agonists, trans-( \pm )-1amino-1,3-cyclopentanedicarboxylate (t-ACPD; R esearch Biochemicals), and (2S,1'S,2'S)-2-carboxycyclopropyl-glycine (LCCG-I; Tocris Cookson). The $\mathrm{Ca}^{2+}$ rise in response to GABA plus the mGluR agonist was compared with the $\mathrm{Ca}^{2+}$ rise in response to GA BA ( $5 \mu \mathrm{M})$ alone. U sing as a criterion a decrease in the $\mathrm{Ca}^{2+}$ elevation by at least $20 \%$, we found that C C G evoked a substantial inhibition of the GABA-mediated $\mathrm{Ca}^{2+}$ rise (Fig. 3). T wenty-three percent of 104 neurons tested showed a CCG mediated reduction in $\mathrm{GA} B \mathrm{~A}$-evoked $\mathrm{C}^{2+}$. B ecause not all cells may express CCG-sensitive mG luR receptors, we compared the $20 \%$ of the cells showing the greatest inhibition in each group (CCG-treated or a second application of GABA as a control). The group $(n=21)$ that received GABA plus CCG showed a $34 \%( \pm 2 \%$ SE M ) reduction of its response to $G A B A$ alone. This difference was highly significant (t test; $p<0.0001$ ). t-ACPD generated a modest inhibition (not statistically significant) of GABA-evoked $\mathrm{Ca}^{2+}$, with $14 \%$ of 103 cells showing a response decrement $>20 \%$. A s a control for the reproducibility of the GABA-mediated $\mathrm{Ca}^{2+}$ rise, we added GABA a second time. Only $6 \%$ of the cells $(n=104)$ showed a change $>20 \%$. When compared with a group $(n=32)$ receiving GA BA plus kainate ( 5 $\mu \mathrm{M}$ ), the group treated with GABA plus CCG showed a much greater decrease ( $t$ test; $p<0.0001$ ). Thus, activation of a CCG sensitive $\mathrm{mG}$ luR inhibited GA BA-mediated $C \mathrm{a}^{2+}$ rises, probably at a postsynaptic site, as described for $\mathrm{mGluR}$ activation in other systems ( $L$ achica et al., 1995).

\section{Presynaptic inhibition of GABA release by group III metabotropic glutamate receptor}

Calcium imaging

U sing fura-2 digital imaging we analyzed the influence of a group III mGluR agonist, L-A P4 (100 $\mu \mathrm{m}$; R esearch Biochemicals), on bath-applied GABA-evoked $\mathrm{Ca}^{2+}$ rises. Muscimol $(5 \mu \mathrm{M})$, a $\mathrm{GABA}_{\mathrm{A}}$ agonist, evoked a $\mathrm{Ca}^{2+}$ peak of $130 \pm 9 \mathrm{~nm}$ (SEM); in the presence of L-AP4 the $C \mathrm{a}^{2+}$ rise was not altered by a substantial amount (117 \pm 9 nм (SEM); $n=46$; statistically insignificant change), indicating little postsynaptic inhibition by L-A P4 (see Fig. 4B). L-A P4 also had no direct effect on $\mathrm{Ca}^{2+}$; in the presence of tetrodotoxin (TTX, $1 \mu \mathrm{M}$ ) to block action potential-mediated transmitter release, the $C \mathrm{a}^{2+}$ levels were the same in the presence of L-A P4 $(82 \pm 2 \mathrm{~nm})$ as in the absence of L-A P4 $(84 \pm 2 \mathrm{~nm}, \mathrm{SE} M)$ ( $n=125$ ), suggesting that L-AP4 had no independent effect on calcium regulation in these neurons ( $F$ ig. $4 \mathrm{~A}$ ).

To examine the action of L-A P4 on synaptic release of GA BA in the absence of T TX, all experiments were done in the presence of $D, L-A P 5(100 \mu \mathrm{M})$ and CNQX $(10 \mu \mathrm{M})$ to block glutamate receptor activation. In this situation, $\mathrm{C}^{2+}$ transients were caused by synaptic release of GABA; bicuculline ( $30 \mu \mathrm{m})$ blocked the transients (Fig. 4C,D). B efore addition of L-A P4 the mean $C \mathrm{a}^{2+}$ rise after bicuculline withdrawal was $98 \pm 7$ (SEM) nM. When L-AP4 was bath-applied, the $\mathrm{Ca}^{2+}$ level decreased to $73 \pm 6$ (SEM ) nm, a statistically significant decrease ( $p<0.01 ; n=65$ ). Fifty-one percent of 65 neurons showed a depression ( $>20 \%$ ) of the GABA-evoked $\mathrm{Ca}^{2+}$ rise in the presence of L-AP4 (Fig. $4 C-E)$.

\section{Inhibitory action of L-AP4 in developing spinal cord and cortical neurons}

The above experiments were based entirely on hypothalamic neurons. To test the hypothesis that activation of group III mG luR s would depress excitatory GABA actions in neurons from other 

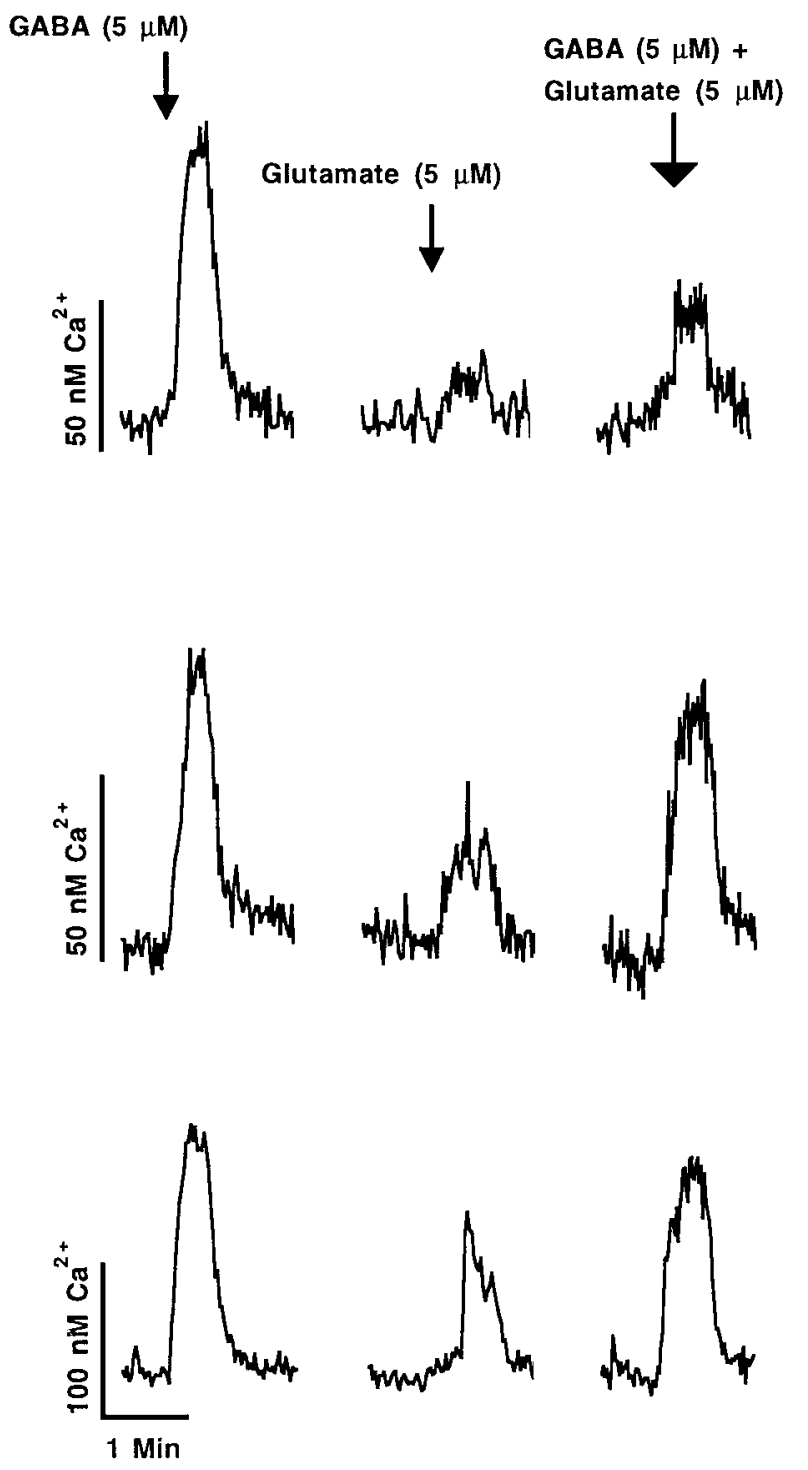

Figure 2. G lutamate reduces the amplitude of GA BA-mediated calcium rises. In three hypothalamic neurons recorded simultaneously with digital fura-2 imaging after $3 \mathrm{~d}$ in vitro, both GA BA $(5 \mu \mathrm{M})$ and glutamate $(5 \mu \mathrm{M})$ evoked $\mathrm{Ca}^{2+}$ rises. In these neurons the rise evoked by GABA is of greater amplitude than that evoked by glutamate. The addition of glutamate to GABA reduced the amplitude of the GABA-evoked $\mathrm{Ca}^{2+}$ rise. E ach transmitter was applied for $30 \mathrm{sec}$ and allowed a 5 min recovery time before the next transmitter application.

parts of the C NS, we also examined 4-6 DIV cultures of cortex or spinal cord neurons. In both regions we found an inhibition of the $\mathrm{Ca}^{2+}$-elevating actions of G A BA by L-A P4 (50 $\left.\mu \mathrm{M}\right)$. B ased on cells that showed at least a $20 \mathrm{~nm}$ rise in $\mathrm{Ca}^{2+}$ in response to bicuculline washout, 13 of 21 spinal cord neurons and three of four cortical neurons showed a decrease in $\mathrm{Ca}^{2+}$ in the presence of L-A P4 (Fig. 5). A II experiments were done in the presence of ionotropic glutamate receptor antagonists. In the presence of bicuculline (20 $\mu \mathrm{M})$, no effect of L-A P4 was detected, suggesting that the L-A P4 actions were dependent on $G A B A$ acting at a $G A B A_{A}$ receptor.

\section{Metabotropic glutamate receptor inhibition of GABA} activity in slices of developing hypothalamus

To test the hypothesis that metabotropic glutamate receptor activation suppresses $\mathrm{GABA}_{\mathrm{A}}$-mediated activity in neonatal hypotha-
A
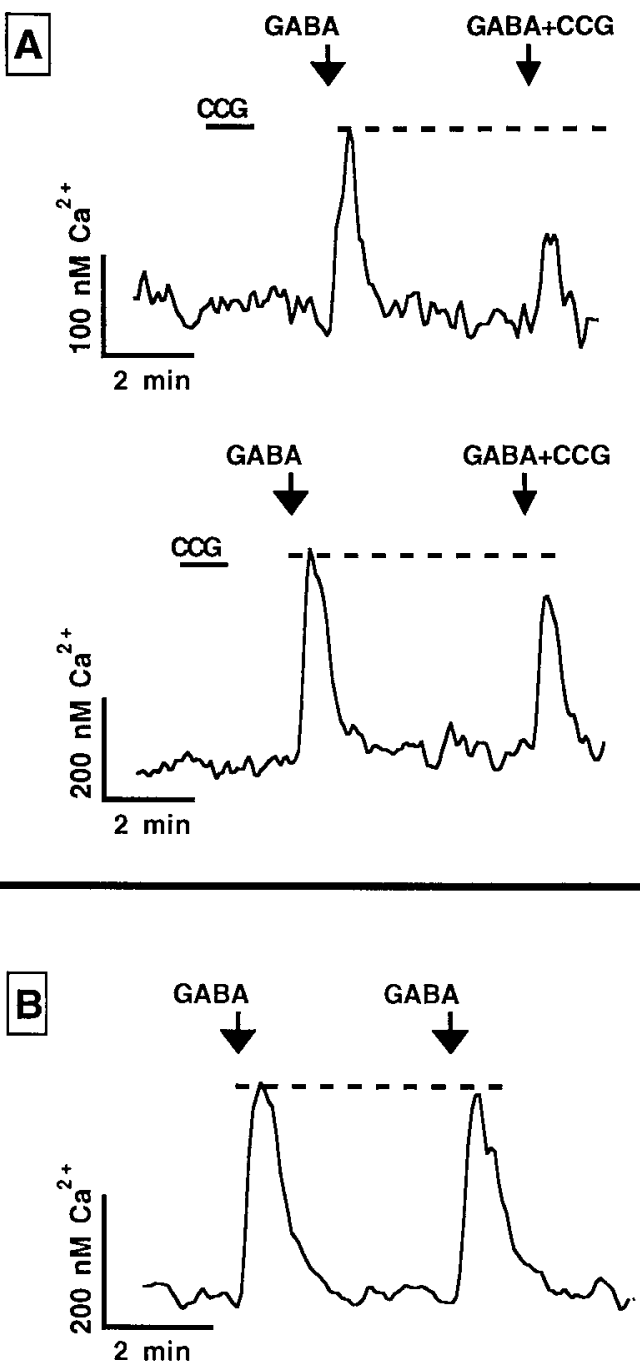

Figure 3. Group II metabotropic glutamate receptor agonist reduces $\mathrm{Ca}^{2+}$ response to GABA. A, T wo neurons from different hypothalamic cultures show no direct $\mathrm{Ca}^{2+}$ response to the group II metabotropic glutamate receptor agonist CCG alone, but when CCG $(50 \mu \mathrm{M})$ is added together with GA BA $(5 \mu \mathrm{M})$, a substantial decrease in the GA BA -evoked $\mathrm{C}^{2+}$ rise is found. $\mathrm{B}$, In a control experiment, a typical cell showed similar amplitude $\mathrm{C} \mathrm{a}^{2+}$ rises in response to GABA $(5 \mu \mathrm{M})$.

lamic slices, we examined the effect of micropipette application to the slice surface (C hristian and Dudek, 1988) of the selective mG luR agonist L-AP4 (100 $\mu \mathrm{M})$ on the frequency of spontaneous GA BA ergic PSPs in A C SF containing C NQX (25 $\mu \mathrm{M})$ and A P5 $(50 \mu \mathrm{M})$. U sing as a criterion PSPs $\geq 10 \mathrm{mV}$ in amplitude, we found that L-AP4 caused a reversible suppression of the frequency of spontaneous GABA ergic PSPs in all arcuate and ventromedial nucleus neurons examined $(n=7$ ) by at least $40 \%$ (range, $40-90 \%$ reduction; mean decrease, $60 \pm 6.9 \% \mathrm{SEM}$ ) (Fig. $6 \mathrm{~A}$ ). I n contrast, application of the control vehicle $(n=2)$ had little effect, thus demonstrating the specificity of L-A P4 actions.

To further test this hypothesis, we also examined the effect of L-AP4 on evoked responses in ACSF containing CNQX and A P5. In five of five arcuate nucleus cells recorded, L-A P4 reversibly caused either a complete blockade or a substantial reduction of the amplitude of PSPs generated by electrical stimulation in an area at the border of the arcuate and ventromedial nuclei (Fig. $6 B, C 1-C 3)$. A t a baseline membrane potential of $-70 \mathrm{mV}, \mathrm{L}-\mathrm{A}$ P4 

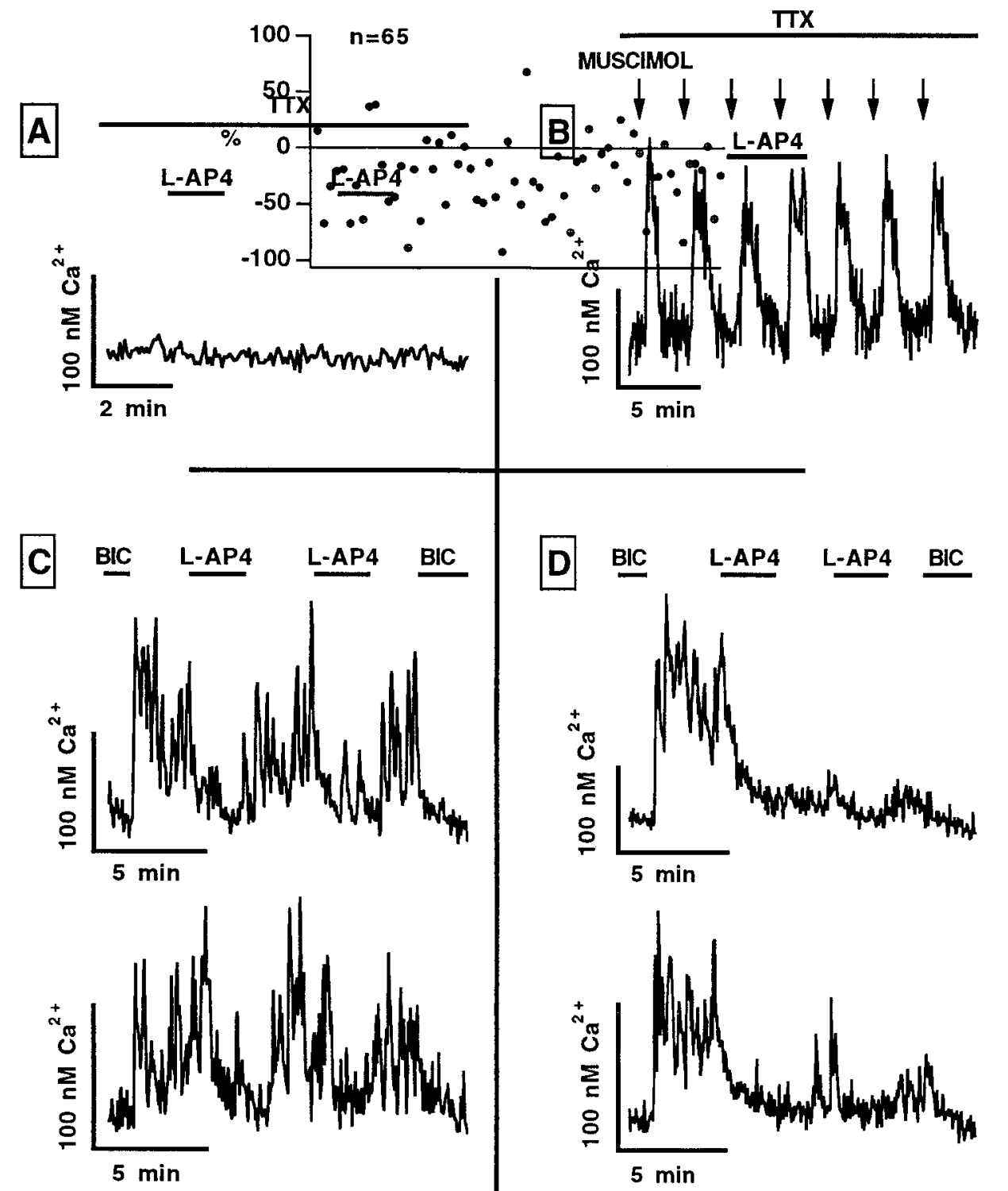

Figure 4. Group III metabotropic receptor activation modulates GABA-elevating actions presynaptically but not postsynaptically. A, L-A P4 (100 $\mu \mathrm{M})$, a group III metabotropic glutamate receptor agonist, elicited no $\mathrm{Ca}^{2+}$ change in the presence of tetrodotoxin (TTX; $1 \mu \mathrm{M}$ ) in cultured hypothalamic neurons. B, L-A P4 $(100 \mu \mathrm{M})$ did not modulate $C \mathrm{a}^{2+}$ rises in response to the $\mathrm{GABA}_{\mathrm{A}}$ receptor agonist muscimol $(5 \mu \mathrm{M})$, depicted in a typical neuron that showed a $\mathrm{Ca}^{2+}$ rise in response to muscimol in the presence of TTX $(1 \mu \mathrm{M})$. These data suggest L-A P4 has little detectable postsynaptic effect on modulating GA BA actions. $C$, In the presence of glutamate receptor antagonists A P 5 (100 $\mu \mathrm{M})$ and C N QX (10 $\mu \mathrm{M})$, synaptically released GA BA-generated $\mathrm{Ca}^{2+}$ rises were blocked by the $\mathrm{GABA}_{\mathrm{A}}$ receptor antagonist bicuculline (BIC; $30 \mu \mathrm{M}$ ). $\mathrm{L}-\mathrm{A} P 4$ reduced the $\mathrm{Ca}^{2+}$ activity in both cells recorded at the same time. Because we found no postsynaptic modulation of GABA by $L-A$ P 4, this suggests an inhibition of GABA release from presynaptic axonal terminals. $D$, Some neurons showed an extended L-A P4 depression of $\mathrm{GABA}$ release as evidenced by the relative lack of recovery after $L-A P 4$ washout. E, This scatterplot shows the effect of L-A P4 on $\mathrm{Ca}^{2+}$ raised by synaptically released GABA. The values were determined by the ratio $\mathrm{Ca}^{2+}$ in control (pre-L-A P4) to the $\mathrm{C} \mathrm{a}^{2+}$ value during L-A P4, and are represented by the percent change. $V$ alues below zero show the percent inhibition of L-A P 4 on $\mathrm{Ca}^{2+}$ levels mediated by synaptically released GABA. Each point represents the percent change in $\mathrm{Ca}^{2+}$ for a single neuron. The zero (0) baseline represents the pre-L-A P4 level for a particular cell.

reduced the amplitude of the evoked GABA-mediated PSP by $90 \pm 4.1 \%$ (SEM ). No significant change was observed in input resistance during L-A P4 application ( $p>0.05$; t test), suggesting that the recording remained stable and that L-A P 4 does not have a direct postsynaptic effect on ion channels on the cell body; this does not preclude the possibility that L-A P4 may modulate the opening of somatodendritic ion channels in response to other factors not studied here.

\section{Electrophysiology of cultured neurons}

In electrophysiological experiments parallel to those described above with $\mathrm{Ca}^{2+}$ digital imaging, we examined the effect of L-A P4 


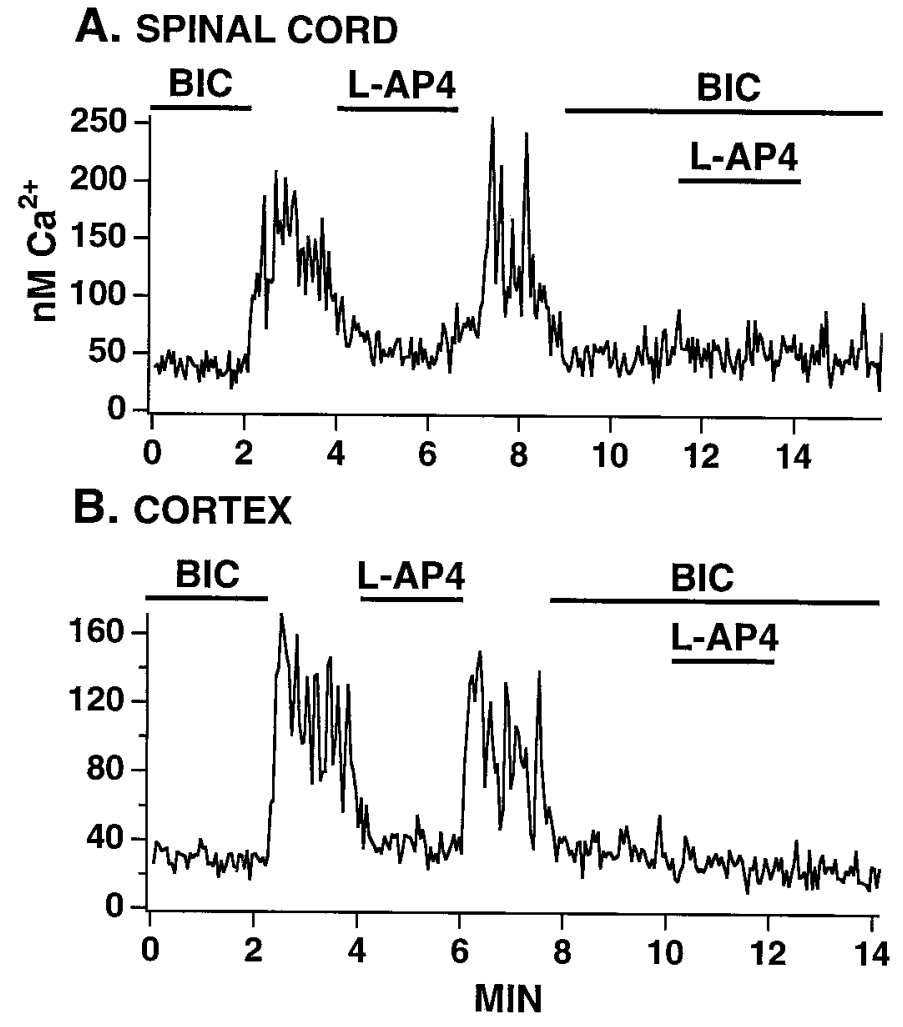

Figure 5. Group III metabotropic receptor agonist depresses excitatory GABA actions in cortex and spinal cord neurons. In spinal cord (A) and cortical (B) neurons cultured for 4- $6 \mathrm{~d}$, and in the presence of A P5 (100 $\mu \mathrm{M})$ and $\mathrm{CNQX}(10 \mu \mathrm{M})$, bicuculline $(20 \mu \mathrm{M})$ depressed calcium levels, indicating a dependence on synaptic GABA activity. L-AP4 (50 $\mu \mathrm{M})$ caused a strong decrease in calcium levels that recovered after L-A P4 washout. In the presence of bicuculline ( $30 \mu \mathrm{M}), \mathrm{L}-\mathrm{A}$ P 4 had no effect on cytosolic calcium, suggesting that its effect was dependent on the excitatory actions of $G A B A$.

(100 $\mu \mathrm{M}$ ) on spontaneous G A BA -mediated postsynaptic currents. These experiments were done in the presence of $D, L-A$ P 5 (100 $\mu \mathrm{M})$ and $\mathrm{CNQX}(10 \mu \mathrm{M})$ to block glutamate actions. In voltage clamp ( $-60 \mathrm{mV}$ holding potential), L-A P4 caused a substantial reduction in the frequency of spontaneous GA BA-mediated EP$\mathrm{SC} S$ in five of six neurons, with a mean reduction by $30 \pm 4 \%$ (mean \pm SE M ) (Fig. 7). L-A P4 evoked a maximum inhibition of $41 \%$ and a minimum inhibition of $20 \%$. This decrease in EPSC frequency was statistically significant ( $t$ test; $p<0.01$ ). C onsistent with the $\mathrm{Ca}^{2+}$ imaging and slice electrophysiology data, no independent effect of L-A P4 (100 $\mu \mathrm{M})$ on membrane potential was found. No difference in the postsynaptic current evoked by GABA $(5 \mu \mathrm{M})$ was found in the presence or absence of L-A P4 $(100 \mu \mathrm{M})(\mathrm{n}=4)$ (data not shown), indicating a lack of effect of L-A P 4 on postsynaptic actions of GA BA and suggesting presynaptic actions, as addressed below.

\section{G ramicidin recordings}

Neurons in these experiments were recorded during early development, after 3-5 d in vitro, and at the period when GABA has depolarizing actions, in contrast to the hyperpolarizing actions found in mature neurons. Although GABA evoked inward currents in the experiments above, this in large part was caused by the choice of pipette solutions. We therefore did additional experiments to demonstrate that the inward postsynaptic currents would be found not only with conven- tional whole-cell recording, but also in neurons with undisturbed intracellular $\mathrm{Cl}^{-}$levels recorded with gramicidinperforated patches (M yers and H aydon, 1972; R eichling et al., 1994; Ebihara et al., 1995). Gramicidin was added to the pipette solution, and whole-cell recordings were obtained, as previously described (van den Pol et al., 1997; G ao et al., 1998). U sing gramicidin-perforated patches, neurons ( 70 of 70 cells in the present study and a previous paper by Gao et al., 1998) at this stage of development between 3 and $5 \mathrm{~d}$ in vitro show very consistent depolarizing responses to bath-applied GABA (5-30 $\mu \mathrm{M}$ ) and to synaptically released GABA. The mean resting membrane potential with gramicidin recordings was $-50.9 \pm 12.3$ (SD) $\mathrm{mV}(\mathrm{n}=32)$. In three of three neurons tested, L-A P4 $(100 \mu \mathrm{M})$ caused a $32+3 \%$ (mean \pm SEM) decrease in the frequency of GABA-mediated excitatory (inward) postsynaptic currents (data not shown). The frequency recovered after washout of the L-A P4. Parallel experiments with gramicidin-based recording have shown depolarizing actions of GABA in slices of developing cortex ( $O$ wens et al., 1996). Bicarbonate and $\mathrm{Cl}^{-}$both pass through the $\mathrm{GABA}$ gated anion channel (K aila, 1994) and, in dendrites of mature dentate granule cells, the depolarizing actions of GABA are dependent on both $\mathrm{Cl}^{-}$and bicarbonate (Staley et al., 1995). In contrast, as the depolarizing action is seen clearly in the present study in $\mathrm{H}$ EPES buffer lacking bicarbonate, only $\mathrm{Cl}^{-}$ appears to be necessary for the depolarizing actions of GA BA in developing neurons (O brietan and van den Pol, 1996); this does not argue against additional actions of bicarbonate but suggests they are not critical for the depolarizing action of GA BA.

\section{M iniature GA BA-mediated EPSC S}

To further demonstrate that the actions of L-AP4 were presynaptic, we used $1 \mu \mathrm{M}$ TTX to block action potentials, and recorded miniature EPSC S (mEPSC s) in the presence of A P5 (100 $\mu \mathrm{M})$ and $\mathrm{CNQX}(10 \mu \mathrm{M})$ to block ionotropic glutamate receptor actions. In buffer that contained T TX, small mE PSC s, ranging in amplitude up to $40 \mathrm{pA}$ were detected. These were blocked by bicuculline $(30 \mu \mathrm{M})$, showing that they were caused by GABA release from presynaptic axons. L-A P4 (100 $\mu \mathrm{M})$ caused a reversible reduction in the frequency of miniature GABA-mediated E PSC s in eight of eleven cells tested (Fig. 7), decreasing the mean GA BA-mediated mEPSC frequency by $51 \pm 5 \%$ (mean \pm SEM ) of pre-L-AP4 control levels, with a maximum decrease of $71 \%$ and a minimum decrease of $34 \%$ from control levels.

\section{Ongoing inhibition of GABA excitation at group III metabotropic glutamate receptors}

To test the hypothesis that there is an ongoing and spontaneous activation of group III mG luR s in hypothalamic neurons, we used a group III antagonist, R, S- $\alpha$-methylserine phosphate (M SO P; $200 \mu \mathrm{M}$ ), as previously described (Thomas et al., 1996; Faden et al., 1997; O 'L eary et al., 1997). A Il experiments were done in the presence of AP5 $(100 \mu \mathrm{M})$ and CNQX (10 $\mu \mathrm{M})$ to block ionotropic glutamate receptors. U sing voltage clamp recording, we first showed that in the presence of AP5 and CNQX, all inward currents could be blocked with bicuculline ( $30 \mu \mathrm{M})$, indicating that they were caused by synaptic G A BA release (Fig. 8A). When $M$ SOP was added by bath application, we found that in six of six neurons tested, there was an increase in GABA activity ( $p a i r e d$ test; $p<0.05$ ), with a mean increase in the frequency of PSC s of $22 \pm 8 \%$ and a maximum increase of $58 \%$ (Fig. $8 \mathrm{~B}$ ). A fter MSOP washout, the frequency of PSC $s$ dropped to 
Metabotropic glutamate receptor activation suppresses spontaneous and evoked GABA-mediated PSPs in neonatal hypothalamic slices

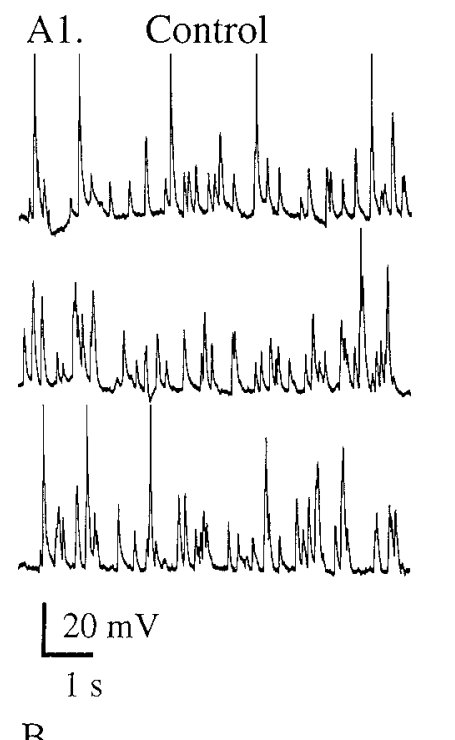

B

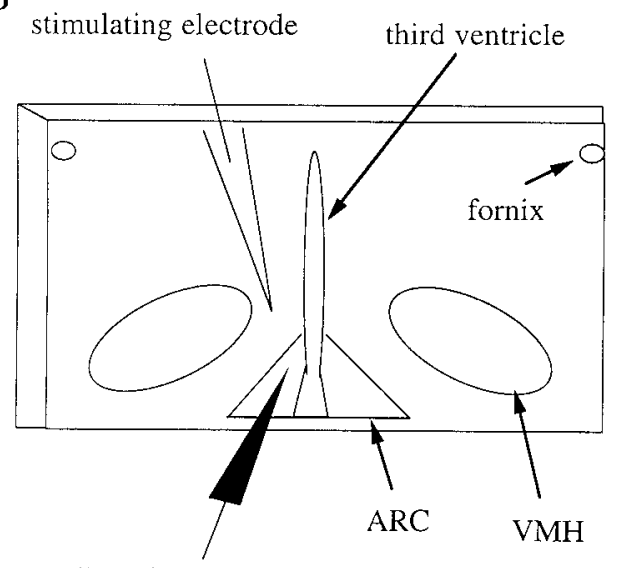

recording pipette

(all in AP5 \& CNQX)
A2. L-AP4
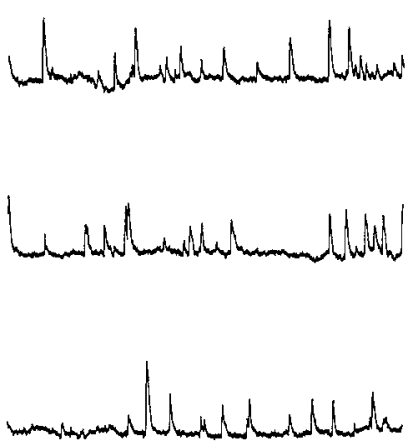

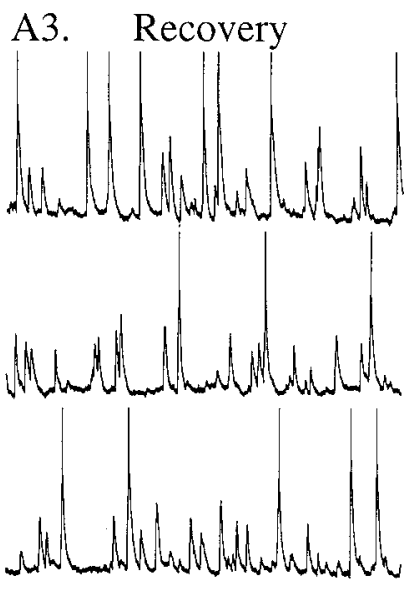

C1.

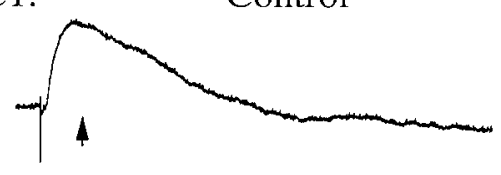

C2.

L-AP4

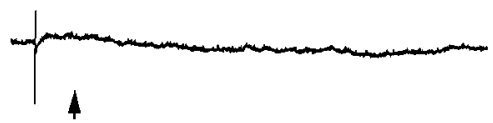

C3.

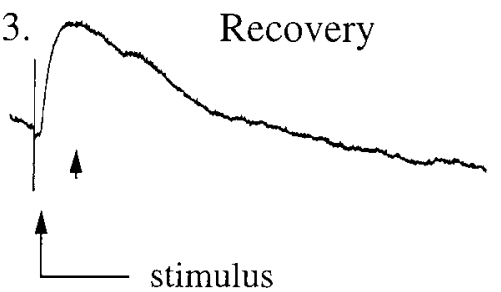

Figure 6. M etabotropic glutamate receptor activation suppresses spontaneous and evoked GABA-mediated PSPs in the neonatal hypothalamic slice. A, The frequency of spontaneous GA BA ergic PSPS recorded from a postnatal day $4 \mathrm{ARC}-\mathrm{VMH}$ neuron was reversibly suppressed by the addition of L-A P4 $(100 \mu \mathrm{M})$. The membrane potential of this neuron was held at approximately $-95 \mathrm{mV}$ throughout the experiment, and the spikes in $A 1$ and $A 3$ are clipped. B, Schematic diagram demonstrating the approximate configuration of stimulating and recording pipettes used in the experiments examining the effect of metabotropic glutamate receptor activation on evoked GABA mediated PSPs. C, A pplication of L-A P4 $(100 \mu \mathrm{M})$ reversibly suppressed monosynaptically evoked GABA-mediated PSPs in a P5 ARC-VMH neuron. In this experiment monosynaptic PSPS (small arrow) were examined by delivering an electrical stimulus at the junction of the ventromedial and arcuate nuclei; L-A P4 showed a substantial reduction in PSP amplitude. The baseline membrane potential of this neuron was held at approximately $-70 \mathrm{mV}$ in the examples shown here. slightly below baseline levels (Fig. 8C). These data suggest that there is an ongoing activation of the mGluRs that inhibits GABA activity, and that when this is blocked an increase in GA BA activity ensues.

\section{Gene expression of metabotropic glutamate receptors in developing brain}

Because the physiological experiments suggest an inhibitory role for metabotropic glutamate receptors, we prepared Northern blots of mRNA to study gene expression of the eight known metabotropic glutamate receptors (Nakanishi, 1994; Schoepp, 1994; Pin and Duvoisin, 1995) in a development series ranging from E 15 embryos to adult (Fig. 9). Because each of the primary three groups of mGluR s is composed of two or more types, the Northern blots allow an analysis of which of the mG luR $s$ within each group are expressed at a developmentally early time. These may be the ones underlying the early actions of group-specific agonists found in the physiological experiments reported above with whole-cell recording and calcium digital imaging. A developmental series of hypothalamus was compared with hippocampus, cortex, olfactory bulb, cerebellum, and whole brain. Three different developmental Northern blots were made, and each showed similar results. The data from one of the blots are shown here, probed with each of the mGluRs, stripped, and then reprobed for the next. In parallel with the electrophysiology and calcium imaging results, analysis of the Northern blot (Fig. 9) suggests that many of the mGluR s were expressed very early in development. Even in embryonic brain tissue, expression of mGluR 1, mGluR 3, mG IuR 5, mG luR 7a, and mG luR 8 could be detected. By the day of birth (P1) expression of all three groups of mGluR s was found. At P1, group I (mGluR 1 and mGluR 5), group II (mGluR3), and group III (mG luR 7a, mGluR 7b, and mGluR 8) are clearly seen in the hypothalamic lane and in many other brain regions. 


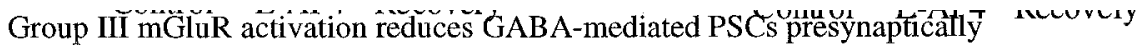

A GABA-mediated spontaneous postsynaptic currents (in CNQX and AP5)

Control L-AP4 Recovery
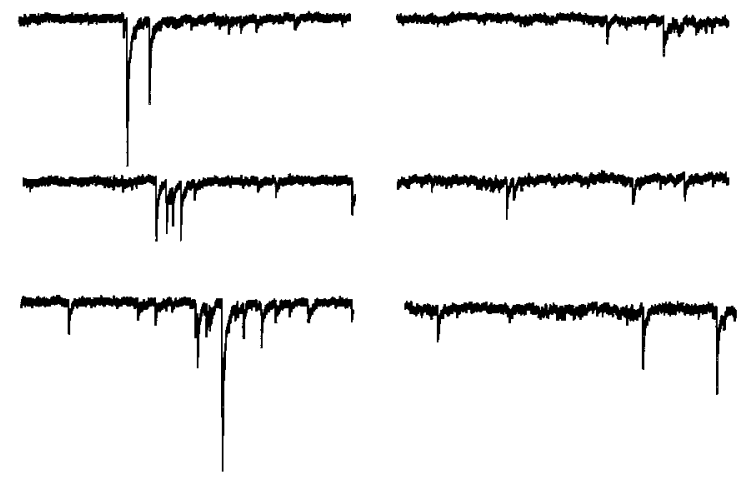
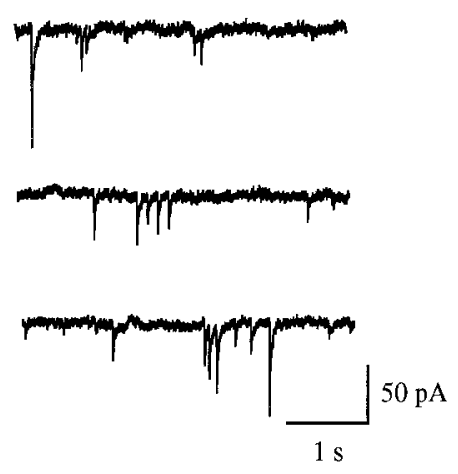

B GABA-mediated miniature postsynaptic currents (in CNQX, AP5 and TTX)

Control

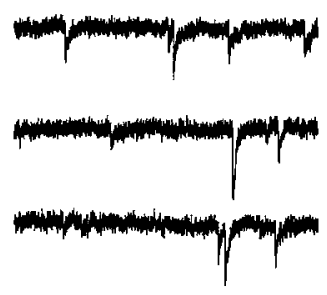

C

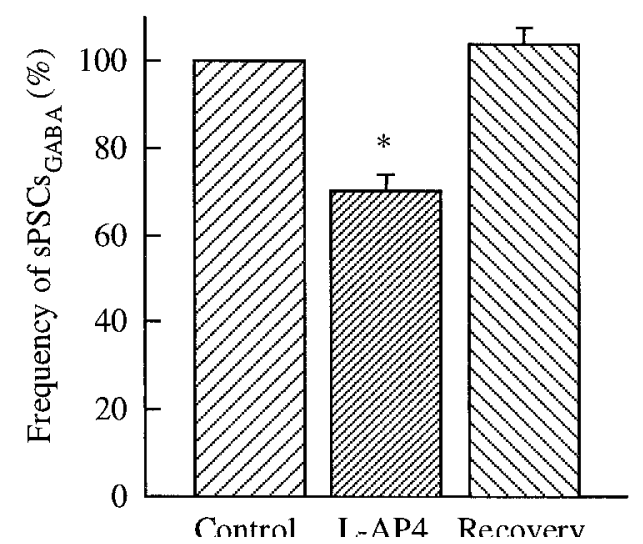

L-AP4

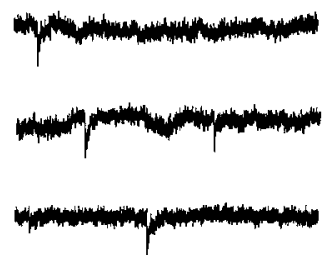

D
Recovery

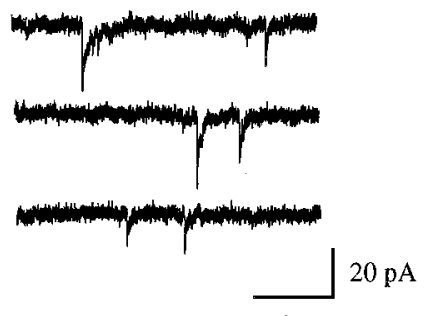

$1 \mathrm{~s}$ APSC $A n$ example of $\mathrm{mEPSC}$ s in the presence of AP5 $(100 \mu \mathrm{M}), \mathrm{CNQX}(10 \mu \mathrm{M})$, and TTX (1 $\mu \mathrm{M})$. The frequency of mE PSC $s$ is reduced by L-A P4. C, The bar graph shows the mean spontaneous E PSC frequency before, during, and after L-A P4 administration in five of six neurons that responded to L-AP4. L-AP4 caused a statistically significant (t test; $p<0.05$ ) decrease in GA BA-mediated EPSC frequency. $D$, The bar graph shows the mean frequency shift in GABAmediated mEPSC frequency before, during, and after L-A P4 administration. The star denotes a statistically significant ( $t$ test; $p<0.05$ ) inhibition of MEPSC frequency in the presence of L-A P 4 in 8 of 11 neurons.

Figure 7. Group III metabotropic glufrequency of spontaneous and miniature GA BA-mediated EPSC S. A, In this typ-
ical hypothalamic neuron in culture, the addition of L-A P4 (100 $\mu \mathrm{M})$ reduced the presence of glutamate receptor antago-

\section{DISCUSSION}

The data presented here suggest that during the developmental period when GABA exerts depolarizing actions, glutamate can and does act to reduce this excitatory activity at both presynaptic and postsynaptic sites. Postsynaptically, acting at a group I/II metabotropic receptor, glutamate inhibits the calcium increase in response to GABA-mediated depolarization. Presynaptically, acting at a group III metabotropic receptor, glutamate can reduce $G A B A$ release. Blocking the group 11 l receptor leads to an increase in GABA activity, suggesting an ongoing inhibition of GABA activity by this glutamate receptor.

\section{'Calcium regulation in developing neurons}

What are the functional ramifications of a glutamate-mediated inhibition of GABA-regulated calcium rises? R egulation of $\mathrm{cy}$ - tosolic calcium levels may be a critical aspect of the depolarizing actions of GABA, and these are not dependent on generating action potentials in a postsynaptic cell, but can be evoked simply by activation of voltage-dependent calcium channels. In fact, in a number of contexts, GABA activation of calcium influx could be of greater significance to developing neurons than evoking action potentials. Changes in cytoplasmic calcium can regulate gene expression (Vaccarino et al., 1992), cell division of neuronal progenitor cells (L OT urco et al., 1995), migration of developing neurons (K omuro and R akic, 1996), and programmed cell death ( $L$ ampe et al., 1995). A lthough no calcium-elevating effect of GABA was found in hippocampal neurites ( $M$ attson and $K$ ater, 1989), in developing hypothalamic neurons, GA BA can act locally to increase calcium within restricted regions of neurites, 
Group III mGluR inhibition increases GABA-mediated PSCs (all in AP5 and CNQX)

A
Control
Bicuculline
Recovery
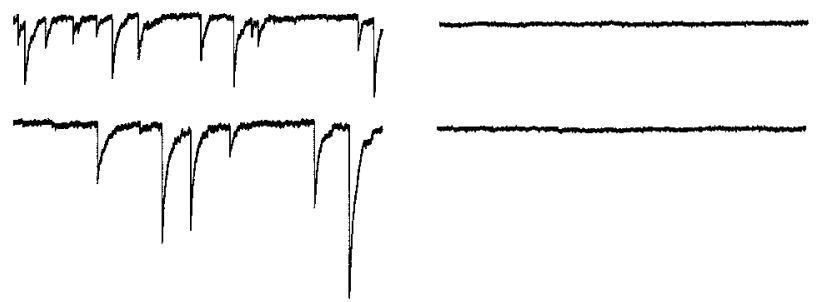

$\mathrm{B}$

Control
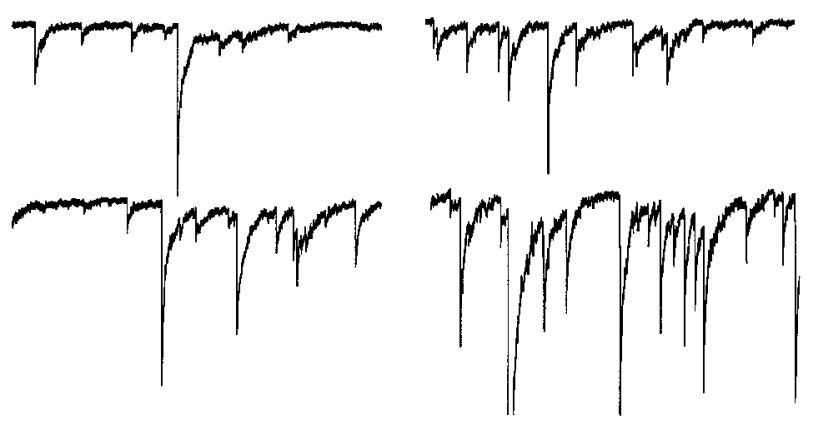

MSOP

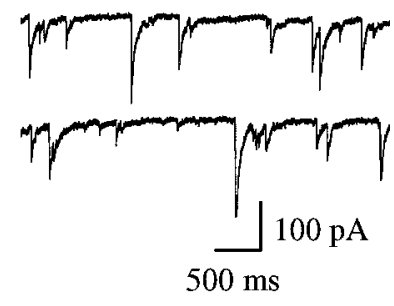

Recovery

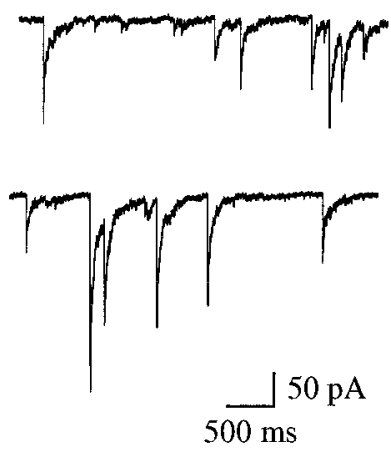

$\mathrm{C}$

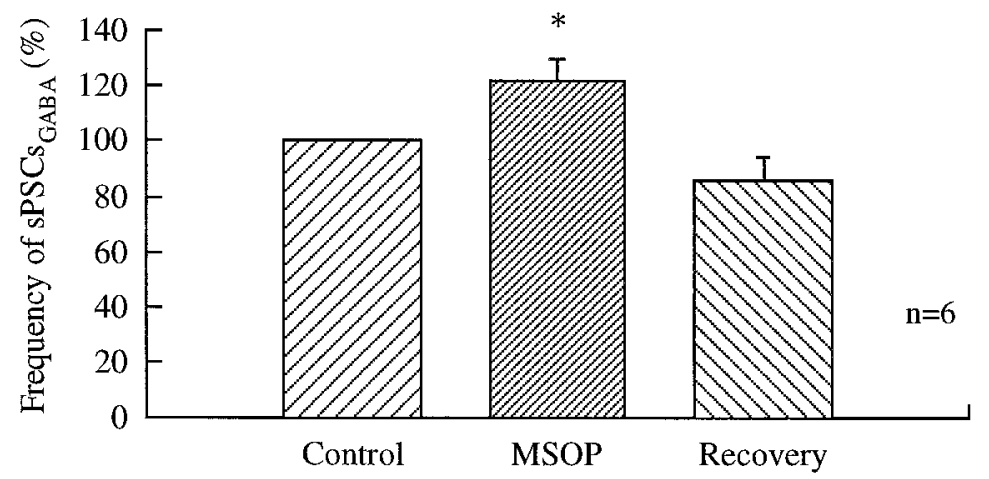

Figure 8. M etabotropic glutamate receptor antagonist potentiates GA BA activity. A, In the presence of AP5 (100 $\mu \mathrm{M})$ and CNQX $(10 \mu \mathrm{M}), \mathrm{PSC} s$ are completely blocked by bicuculline $(30 \mu \mathrm{M})$ in synaptically coupled hypothalamic neurons in culture. A fter washout, recovery is found. These data indicate that PSC s in these conditions are solely caused by synaptic release of GABA. In these experiments, $\mathrm{KCl}$ was used in the recording pipette. $\mathrm{B}$, The group III antagonist MSOP $(200 \mu \mathrm{M})$ causes an increase in the frequency of G A BA -mediated PSC s that recovers after MSOP washout. $C$, In this bar graph, the data from all six neurons are combined. Blocking of the group III mGluR by M SO P causes a significant ( $p<0.05$; paired $t$ test) increase in the frequency of GABAmediated PSC s. A fter M SOP washout, the frequency of PSC $S$ decreases. These data support the view that there is an ongoing inhibition of GABA activity in developing hypothalamic neurons by activated $\mathrm{mGluR}$ receptors. growth cones, or developing neuronal perikarya (Obrietan and van den Pol, 1996). By increasing calcium, GA BA can therefore alter neurite and growth cone extension and direction of growth ( $M$ attson and $K$ ater, 1987; $K$ ater and $M$ ills, 1991; R ehder and K ater, 1992; Z heng et al., 1994) and increase transmitter release. $L$ ocal GABA-evoked calcium rises at specific regions of the plasma membrane may also play a role in GA BA receptor protein aggregation, as shown for similar excitatory actions of glycine in developing spinal cord neurons (K irsch and B etz, 1998). Because the specific level of cytosolic calcium may be critical for many of the actions described here, the ability of glutamate to reduce the amplitude of a calcium rise generated by GA BA gives glutamate an important modulatory role.

GABA is found in high concentrations in growth cones of developing axons before synapse formation (van den Pol, 1997); if it is released from the growing axon, as the transmitter acetylcholine is released from neurites of developing motorneurons
(Hume et al., 1983; Y oung and Poo, 1983), then a growing GA BA ergic axon could potentially initiate communication with a prospective postsynaptic target before establishment of a synapse. It may be that the calcium-elevating actions of GA BA constitute a critical part of the early stages of synapse formation. Based on data presented here, glutamate could theoretically inhibit this communication either by inhibition of GABA release from the developing axon or reduction of calcium influx into a potential postsynaptic partner for the growing GABA ergic axon.

G lutamate inhibition of the excitatory actions of GABA would only occur during an early transient phase of neuronal development, but during this time period the inhibitory actions appear robust. In this paper we found that in almost all neurons that showed a greater calcium response to GA BA than to glutamate, that together, glutamate would reduce the amplitude of the GA BA-mediated calcium rise. We have previously shown that in very early stages of development, the majority of neurons show a 


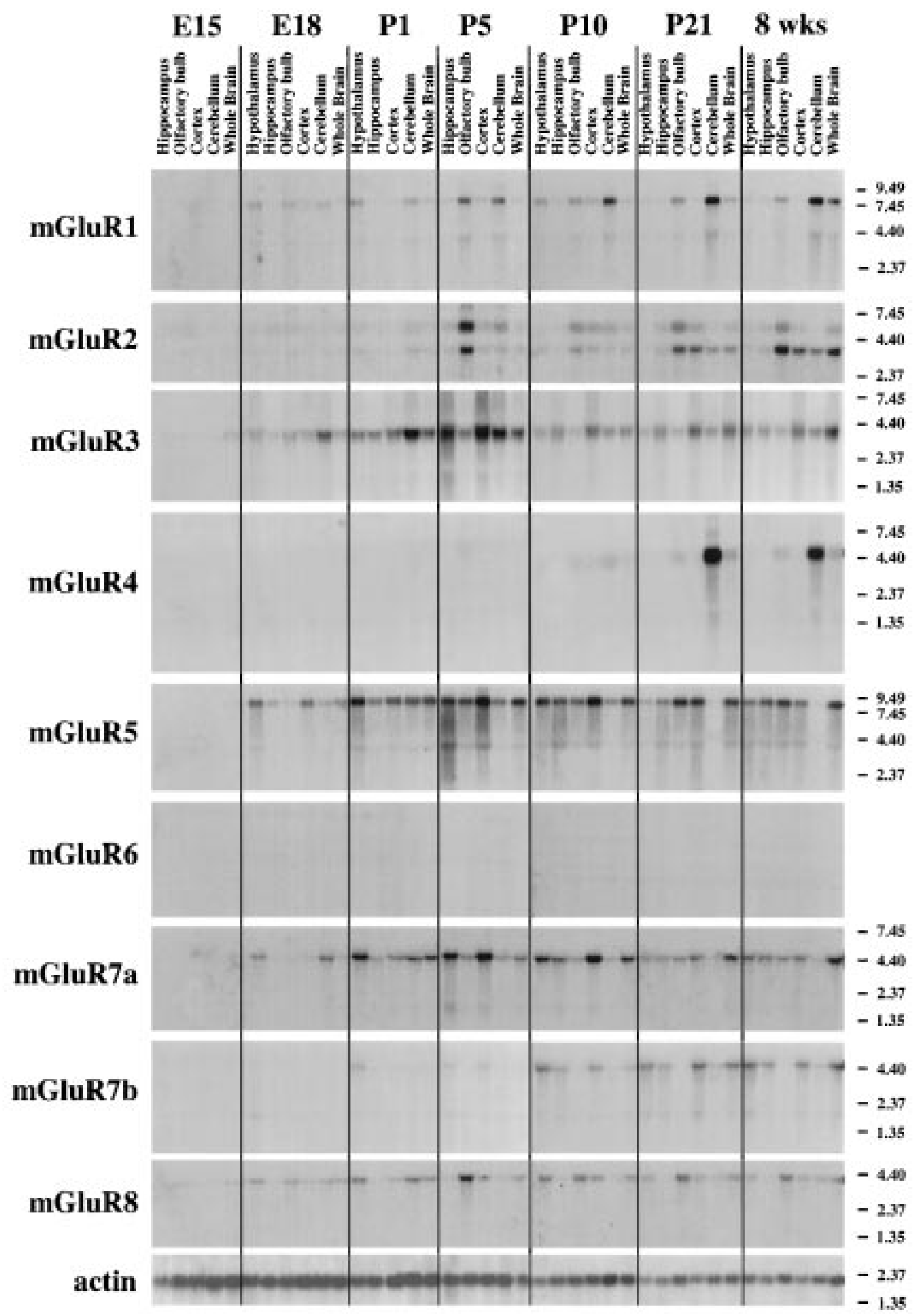

Figure 9. M etabotropic glutamate receptors: developmental expression examined with Northern blot. Ten micrograms of R N A samples were loaded from hippocampus, hypothalamus, cortex, cerebellum, olfactory bulb, and whole brain at different development time points from E 15 to adult ( 8 weeks) $\mathrm{E}$ ach lane is based in a mixture of tissue from three rats. Even in the embryonic brain at E 18, expression can be detected for some of the mG luR $\mathrm{s}$, suggesting early expression. A the bottom are control lanes showing actin R N A. The slightly higher level of expression of actin in developing brain can be interpreted as a greater level of actin synthesis rather than differential loading. 
greater calcium rise in response to GABA than to equimolar concentrations of glutamate (O brietan and van den Pol, 1995). This suggests that during the early period of hypothalamic development when the $\mathrm{Cl}^{-}$reversal potential is positive to the membrane resting potential, the inhibition of GA BA -mediated elevations in neuronal calcium by glutamate would be substantial.

A Ithough under certain conditions the developing brain may be somewhat more excitable than the adult brain (Schwartzkroin, 1984; Hablitz, 1987; Swann et al., 1988), excessive activity is normally not found during development. O ne reason that the role of GABA as an excitatory transmitter in development does not result in runaway excitation when coupled with glutamate actions may be that glutamate can reduce GABA excitation, both at presynaptic and postsynaptic glutamate receptors. As neurons develop, the roles of GABA and glutamate change. Glutamateevoked calcium rises increase in amplitude, whereas those evoked by $\mathrm{GA} \mathrm{BA}$ disappear as the $\mathrm{Cl}^{-}$reversal potential gradually shifts in a negative direction (O brietan and van den Pol, 1995; van den Pol et al., 1995; Chen et al., 1996).

\section{Metabotropic glutamate receptors}

O ur physiological data and Northern blot analysis showing that both presynaptic and postsynaptic metabotropic glutamate receptors are expressed and functionally active during early periods of development supports their potential role in the inhibitory modulation of early neuronal activity and synapse formation.

The physiological studies demonstrate that at least two groups of $\mathrm{mG}$ luR s may participate in inhibitory actions during development; the Northern blot analysis suggests that most of the mGluR s (Nakanishi, 1994), with the exception of mGluR 6, are expressed during development and could contribute to the physiological actions found. Based on whole-cell recording in both cultured hypothalamic neurons and in slices of the developing hypothalamus, we find that activation of group III mG IuR s causes a widespread inhibition of GABA action, primarily by presynaptic inhibition of GABA release. In fact, in hypothalamic slices, activation of group III mG luR s almost completely blocked ( $90 \%$ inhibition) the evoked GABA-mediated PSP in the arcuate nucleus region. Given the strong expression of $m G$ luR 7a $m R N A$ we find in Northern blots of the developing hypothalamus, this may be the group III receptor involved in this inhibition. Together, these results are in strong support of the idea that mG luR s are expressed very early in neuronal development on presynaptic G A B A ergic axons that are in the process of establishing synapses. Thus, glutamate activation of these receptors would tend to reduce $G A B$ A ergic excitation by inhibition of release. $E$ xpression of mGluR mRNA early in development is found not only in hypothalamus, but also to varying degrees in other brain regions examined for comparison, suggesting that many of the inhibitory actions of $\mathrm{mG}$ luR $\mathrm{s}$ on GABA-mediated excitation described in this paper relating to hypothalamic neurons may also be present in other brain areas, as supported by our parallel work on spinal cord and cortical neurons.

mGluR inhibition of release of GABA and other transmitters is not unique to developing neurons but has also been described in mature neurons in the hippocampus ( $G$ ereau and Conn, 1995), hypothalamus ( $C$ hen and van den Pol, 1998), and elsewhere (Nakanishi, 1994; Salt and Turner, 1996; Bonci et al., 1997; Schaff hauser et al., 1998). However, in mature neurons, inhibition of GABA would ultimately have a fundamentally different effect; reducing GABA-mediated inhibition would tend to increase excitation by disinhibition. A primary point of our results is the fact that functional mGluRs are strongly expressed at a very early stage of neuronal development, during a period when synapse formation is just beginning. Furthermore, even at the earliest stages of synapse formation, mGluR activation can exert a powerful depressive action on excitatory GABA activity. M etabotropic glutamate receptors are found early in phylogeny, including in invertebrates in which they may act by similar mechanisms (Parmentier et al., 1996). Partial homology is even found with bacterial periplasmic binding proteins ( 0 'H ara et al., 1993), indicating a possible early evolutionary origin. This raises the speculation whether early in evolution glutamate acting on mGluR s may have mediated inhibitory actions.

\section{Dual role for glutamate}

In the present work we focus on inhibitory actions of glutamate on GABA excitation during the developmental maturation of hypothalamic neurons. These inhibitory actions of glutamate in developing neurons have not been addressed before. U nder other conditions glutamate can also exert direct excitatory actions on developing hypothalamic neurons ( $C$ hen et al., 1995; van den Pol et al., 1995). In addition, during early development, glutamate, acting at AM PA-kainate receptors, can also act synergistically with GABA to evoke action potentials if glutamate receptor activation occurs after GABA-activated $\mathrm{Cl}^{-}$channels have closed but the membrane potential is still partially depolarized ( $G$ ao et al., 1998). In the hippocampus, G A BA can act to depolarize developing neurons, and by relieving the N M DA receptors of their voltage-dependent $\mathrm{Mg}^{2+}$ block, can thereby enhance glutamate-mediated depolarization (Ben A ri et al., 1994; L einekugel et al., 1997). Together, these data show that glutamate can act either to inhibit or enhance the excitatory actions of GABA in developing neurons. D uring development, more synapses are produced than are needed; some are maintained, and others are lost. In line with a H ebbian model of synaptic strengthening, the dual role of glutamate (enhancing or reducing GABA excitation) may give it a crucial role in determining which GA BA ergic synapses get stabilized and which are lost. Because a principal role for GABA in the mature brain is to counteract glutamate-mediated excitation, it seems reasonable that glutamate may play some modulatory role in defining GABAergic synapse formation.

G A BA can play a number of potentially important roles during development. These include regulation of neurite growth, synapse formation, growth cone guidance, cell division, and synapse stabilization. The ability of glutamate to inhibit the excitatory activity of GABA at both presynaptic and postsynaptic sites would allow glutamate to exercise an important modulatory role in early development. $L$ ater in development, glutamate would take on an increasing larger role as the primary excitatory amino acid transmitter.

\section{REFERENCES}

Barbin G, Pollard H, Gaiarsa J L, Ben-A ri Y (1993) Involvement of GABA-A receptors in the outgrowth of cultured hippocampal neurones. Neurosci L ett 152:150-154.

Belousov A B, van den Pol AN (1997) L ocal synaptic release of glutamate from neurons in the rat hypothalamic arcuate nucleus. J Physiol (L ond) 499:747-761.

Ben-A ri Y, Tseeb V, Raggozzino D, K hazipov R, Gaiarsa J L (1994) $G$ amma-aminobutyric acid (GA BA) : a fast excitatory transmitter which may regulate the development of hippocampal neurones in early postnatal life. Prog Brain R es 102:261-273. 
Bonci A, Grillner P, Siniscalchi A, Mercuri N B, Bernardi G (1997) Glutamate metabotropic receptor agonists depress excitatory and inhibitory transmission on rat mesencephalic principal neurons. Eur J Neurosci 9:2359-2369.

Chen G, van den Pol A N (1998) C oexpression of multiple metabotropic glutamate receptors in axon terminals of single suprachiasmatic nucleus neurons. J Neurophysiol 80:1932-1938.

Chen G, Trombley PQ, van den Pol A N (1995) GA BA receptors precede glutamate receptors in hypothalamic development: differential regulation by astrocytes. J N europhysiol 74:1473-1484.

Chen G, Trombley PQ, van den Pol A N (1996) Excitatory actions of GABA in developing rat hypothalamic neurones. J Physiol ( $L$ ond) 494:451- 464.

Cherubini E, Rovira C, Gaiarsa J L, Corradetti R, Ben-A ri Y (1990) GA BA mediated excitation in immature rat CA 3 hippocampal neurons. Int J Dev Neurosci 8:481-490.

Cherubini E, Gaiarsa J, Ben-A ri Y (1991) GA BA : an excitatory transmitter in early postnatal life. Trends N eurosci 14:515-519.

Christian EP, D udek FE (1988) Characteristics of local excitatory circuits studied with glutamate microapplication in the CA 3 area of rat hippocampal slices. J Neurophysiol 59:90-109.

Connor J, Tseng H, H ockberger P (1987) Depolarization-and transmitter-induced changes in intracellular $\mathrm{Ca}^{2+}$ of rat cerebellar granule cells in explant cultures. J Neurosci 7:1384-1400.

D ecavel C, van den Pol A N (1990) GA BA : a dominant neurotransmitter in the hypothalamus. J Comp Neurol 302:1019-1037.

E bihara S, Shirato K , H arata N, A kaike N (1995) Gramicidin-perforated patch recording: GABA response in mammalian neurones with intact intracellular chloride. J Physiol (L ond) 434:77- 86.

Faden A I, I vanova SA, Y akovlev A G, M ukhin A G (1997) Neuroprotective effects of group III mG luR in traumatic neuronal injury. J Neurotrauma 14:885-895.

Gao X B, Chen G, van den Pol A N (1998) GA BA-dependent firing of glutamate-evoked action potentials at non-N M DA receptors in developing hypothalamic neurons. J Neurophysiol 79:716-726.

Gereau RW, Conn PJ (1995) Multiple presynaptic metabotropic glutamate receptors modulate excitatory and inhibitory synaptic transmission in hippocampal area CA 1. J Neurosci 15:6879-6889.

Ghosh PK, Baskaran N, van den Pol A N (1997) Developmentally regulated gene expression of all eight metabotropic glutamate receptors in hypothalamic SC N and arcuate nuclei. D ev Brain R es 102:1-12.

Grynkiewicz G, Poenie M, Tsien R (1985) A new generation of calcium indicators with greatly improved fluorescence properties. J Biol Chem 260:1440-1450.

H ablitz J J (1987) Spontaneous ictal-like discharges and sustained potential shifts in the developing rat neocortex.J N europhysiol 58:1052-1065.

Hume RL, Role L, Fischbach GD (1983) A cetylcholine release from growth cone detected by patches of acetylcholine receptor-rich membrane. Nature 305:632- 634.

K aila K (1994) Ionic basis of $\mathrm{GA} \mathrm{BA}_{\mathrm{A}}$ receptor channel function in the nervous system. Prog Neurobiol 42:489-537.

K ater SB, M ills LR (1991) R egulation of growth cone behavior by calcium. J Neurosci 11:891-899.

$\mathrm{K}$ irsch J, Betz H (1998) Glycine receptor activation is required for receptor clustering in spinal neurons. Nature 392:717-720.

K omuro H, R akic P (1996) Intracellular $\mathrm{Ca}^{2+}$ fluctuations modulate the rate of neuronal migration. Neuron 17:275-285.

L achica EA, R ubsamen R, Z irpel L, Rubel EW (1995) Glutamatergic inhibition of voltage-operated calcium channels in the avian cochlear nucleus. J Neurosci 15:1724-1734.

L ampe PA , C ornbrooks EB, J uhasz A, J ohnson E M , Franklin J L (1995) Suppression of programmed cell death by a thapsigargin-induced $\mathrm{Ca}^{2+}$ influx. J Neurobiol 26:205-212.

L einekugel X, M edina I, K halilov I, Ben-A ri Y, K hazipov R (1997) $\mathrm{Ca}^{2+}$ oscillations mediated by the synergistic excitatory actions of GA BA-A and N M DA receptors in the neonatal hippocampus. Neuron 18:243-255.

L OT urco JJ, O wens DF, H eath M J S, Davis M BE, K riegstein A R (1995) GABA and glutamate depolarize cortical progenitor cells and inhibit DNA synthesis. Neuron 15:1287-1298.

M attson M P, K ater SB (1987) C alcium regulation of neurite elongation and growth cone motility. J Neurosci 7:4034-4043.

M attson M P, K ater SB (1989) E xcitatory and inhibitory neurotransmitters in the generation and degeneration of hippocampal neuroarchitecture. Brain R es 478:337-348.
Michler A (1990) Involvement of GA BA receptors in the regulation of neurite growth in cultured embryonic chick tectum. Int J D ev N eurosci 8:463- 472.

M yers V B, Haydon DA (1972) I on transfer across lipid membranes in the presence of gramicidin A . II. The ion selectivity. Biochim Biophys A cta 274:313-322.

Nakanishi S (1994) Metabotropic glutamate receptors: synaptic transmission, modulation, and plasticity. Neuron 13:1031-1037.

Obrietan K, van den Pol AN (1995) GABA neurotransmission in the hypothalamus: developmental reversal from $\mathrm{Ca}^{2+}$ elevating to depressing. J Neurosci 15:5065-5077.

Obrietan K, van den Pol AN (1996) Growth cone calcium rise by GA BA. J Comp Neurol 372:167-175.

O brietan K, van den Pol A N (1997) GA BA activity mediating cytosolic $\mathrm{Ca}^{2+}$ rises in developing neurons is modulated by CA M P dependent signal transduction. J Neurosci 17:4785-4799.

O'H ara PJ, Sheppard PO, Thogersen H, V enezia D, H aldeman BA, M cGrane V, Houamed K M, Gilbert TL, Mulvihill ER (1993) The ligand-binding domain in metabotropic glutamate receptors is related to bacterial periplasmic binding proteins. Neuron 11:41-52.

O'Leary DM, Cassidy EM, O'Connor JJ (1997) Group II and III metabotropic glutamate receptors modulate paired pulse depression in the rat dentate gyrus in vitro. Eur J Pharmacol 340:35- 44.

$O$ wens DF, Boyce L H, Davis M BE, K riegstein A R (1996) Excitatory GABA responses in embryonic and neonatal cortical slices demonstrated by gramicidin perforated-patch recordings and calcium imaging. J Neurosci 16:6414-6423.

Parmentier M L, Pin J P, Bockaert J, G rau Y (1996) Cloning and functional expression of a Drosophila metabotropic glutamate receptor expressed in the embryonic C NS. J Neurosci 16:6687- 6694.

Pin J-P, Duvoisin R (1995) The metabotropic glutamate receptors: structure and functions. Neuropharmacology 34:1-26.

Rehder V, Kater SB (1992) Regulation of neuronal growth cone filopodia by intracellular calcium. J Neurosci 12:3175-3186.

R eichling D B, Kyrozis A, W ang J, M acD ermott A B (1994) M echanisms of $\mathrm{GABA}$ and glycine depolarization-induced calcium transients in rat dorsal horn neurones. J Physiol (L ond) 476:411- 421.

Reynolds JD, Brien JF (1992) Ontogeny of glutamate and gammaaminobutyric acid in the hippocampus of the guinea pig. J D ev Physiol 18:243-252.

R oberts PJ (1995) Pharmacological tools for the investigation of metabotropic glutamate receptors ( $\mathrm{mG}$ luRs): phenylglycine derivatives and other selective antagonists. N europharmacology 34:813-819.

Salt TE, T urner J P (1996) A ntagonism of the presumed presynaptic action of L-A P4 on GA BA ergic transmission in the ventrobasal thalamus by the novel mGluR antagonist MPPG. Neuropharmacology 35:239-241.

Schaff hauser $H, K$ noflach F, Pink J R, Bleuel Z, C artmell J, G oepfert F, K emp J A, R ichards J G, A dam G, M utel V (1998) M ultiple pathways for regulation of the $\mathrm{KCl}$-induced [ $3 \mathrm{H}$ ]-G A BA release by metabotropic glutamate receptors, in primary rat cortical cultures. Brain Res 782:91-104.

Schoepp DD (1994) N ovel functions for subtypes of metabotropic glutamate receptors. N eurochem Int 24:439-449.

Schwartzkroin PA (1984) Epileptogenesis in the immature central nervous system. In: Electrophysiology of epilepsy (Schwartzkroin PA, Wheal H V, eds), pp 389-412. L ondon: A cademic.

Serafini R, Valeyev AY, Barker J L, Poulter MO (1995) Depolarizing GABA -activated $\mathrm{Cl}^{-}$channels in embryonic rat spinal and olfactory bulb cells. J Physiol (L ond) 488:371-386.

Spoerri P (1988) Neurotrophic effects of GA BA in cultures of embryonic chick brain and retina. Synapse 2:11-22.

Staley K J, Soldo BL, Proctor W R (1995) Ionic mechanism of neuronal excitation by inhibitory $\mathrm{GA} \mathrm{BA}_{\mathrm{A}}$ receptors. Science 269:977-981.

Swann J W, Brady R J, Smith K L, Pierson M G (1988) Synaptic mechanisms of focal epileptogenesis in the immature nervous system. In: $D$ isorders of the developing nervous system: changing views on their origins, diagnoses and treatments (Swann JW, Messer A, eds), pp 19- 49. N ew Y ork: Liss.

Thomas NK, Jane DE, Tse HW (1996) alpha-M ethyl derivatives of serine-0-phosphate as novel, selective competitive metabotropic glutamate receptor antagonists. Neuropharmacology 35:637- 642.

Vaccarino F, H aywark M, Nestler E,D uman R, Tallman J (1992) Dif- 
ferential induction of immediate early genes by excitatory amino acid receptor types in primary cultures of cortical and striatal neurons. $\mathrm{M}$ ol Brain Res 12:233-241.

van den Pol AN (1994) Metabotropic glutamate receptor mG luR 1 distribution and ultrastructural localization in hypothalamus. J Comp Neurol 349:615-632.

van den Pol A N (1997) GA BA immunoreactivity in hypothalamic neurons and growth cones in early development in vitro before synapse formation. J Comp Neurol 383:178-188.

van den Pol A N, K ogelman L, G hosh P, Liljelund P, Blackstone C (1994) Developmental regulation of the hypothalamic glutamate receptor mG luR 1. J Neurosci 14:3816-3834. van den Pol A N, Romano C, Ghosh P (1995) M etabotropic glutamate receptor $m G$ luR 5: subcellular distribution and developmental expression in hypothalamus. J Comp Neurol 362:134-150.

van den Pol AN, Obrietan K, Chen G (1996) Excitatory effects of GA BA after neuronal trauma. J Neurosci 16:4283- 4292.

Y oung SH, Poo M M (1983) Spontaneous release of transmitter from growth cone of embryonic neurone. Nature 305:634-637.

Y uste R, K atz LC (1991) Control of postsynaptic $\mathrm{Ca}^{2+}$ influx in developing neocortex by excitatory and inhibitory neurotransmitters. N euron 6:333-344.

Z heng J Q, Felder M, Connor JA, Poo M M (1994) T urning of nerve growth cones induced by neurotransmitters. Nature 368:140-144. 